\title{
Modelling potential impacts of bottom trawl fisheries on soft sediment biogeochemistry in the North Sea $\uparrow$
}

\author{
Daniel E. Duplisea,*† Simon Jennings, Stephen J. Malcolm, Ruth Parker and David B. Sivyer \\ Centre for the Environment, Fisheries and Aquaculture Sciences (CEFAS), Pakefield Road, \\ Lowestoft, Suffolk, UK NR33 OHT
}

Received 14th September 2001, Accepted 22nd November 2001 Published on the Web 19th December 2001

\section{Article}

Bottom trawling causes physical disturbance to sediments particularly in shelf areas. The disturbance due to trawling is most significant in deeper areas with softer sediments where levels of natural disturbance due to wave and tidal action are low. In heavily fished areas, trawls may impact the same area of seabed more than four times per year. A single pass of a beam trawl, the heaviest gear routinely used in shelf sea fisheries, can kill $5-65 \%$ of the resident fauna and mix the top few $\mathrm{cm}$ of sediment. We expect that sediment community function, carbon mineralisation and biogeochemical fluxes will be strongly affected by trawling activity because the physical effects of trawling are equivalent to those of an extreme bioturbator, and yet, unlike bioturbating macrofauna, trawling does not directly contribute to community metabolism. We used an existing box-model of a generalised soft sediment system to examine the effects of trawling disturbance on carbon mineralisation and chemical concentrations. We contrasted the effects of a natural scenario, where bioturbation is a function of macrobenthos biomass, with an anthropogenic impact scenario where physical disturbance results from trawling rather than the action of bioturbating macrofauna. Simulation results suggest that the effects of low levels of trawling disturbance will be similar to those of natural bioturbators but that high levels of trawling disturbance prevent the modelled system from reaching equilibrium due to large carbon fluxes between oxic and anoxic carbon compartments. The presence of macrobenthos in the natural disturbance scenario allowed sediment chemical storage and fluxes to reach equilibrium. This is because the macrobenthos are important carbon consumers in the system whose presence reduces the magnitude of available carbon fluxes. In soft sediment systems, where the level physical disturbance due to waves and tides is low, model results suggest that intensive trawling disturbance could cause large fluctuations in benthic chemical fluxes and storage.

\section{Introduction}

Bottom trawling is a key source of physical disturbance in shallow shelf seas, and trawling is well known to affect the diversity, community structure, size composition and production of benthic invertebrate communities. ${ }^{1-6}$ However, little is known of the effects of trawling disturbance on processes in the marine ecosystem, despite the expectation that sediment community function, carbon mineralisation and biogeochemical fluxes will be strongly affected by trawling disturbance. Biogeochemical effects of trawling disturbance are expected because (i) trawling reduces the abundance of bioturbating macrofauna that play a key role in biogeochemical processes and (ii) because the physical mixing by trawling may be likened to bioturbation by macrofauna, and yet trawling, unlike the macrofauna, does not directly contribute to community metabolism. ${ }^{7}$

Amongst all the fishing gears used in the North Sea, beam trawls have the greatest physical impact on sediments and their fauna per unit distance towed; ${ }^{3}$ however, otter trawling gear also impacts sediments by cutting furrows in the sediment with the spreader doors. ${ }^{8}$ A matched pair of beam trawls, each of $4 \mathrm{~m}$ to $12 \mathrm{~m}$ width are towed by a single beam trawler. In the

$\uparrow$ Presented during the ACS Division of Geochemistry symposium 'Biogeochemical Consequences of Dynamic Interactions Between Benthic Fauna, Microbes and Aquatic Sediments', San Diego, April 2001.

\$Present address: Institut Maurice-Lamontagne, Mont-Joli, Québec, Canada G5H 3Z4. E-mail: duplisead@dfo-mpo.gc.ca; Fax: +1 1418775 0740; Tel: +14187750881 north-east Atlantic, most beam trawlers fish with two $12 \mathrm{~m}$ beam trawls for flatfish. Each trawl weighs about $8000 \mathrm{~kg}$ (in air) and is towed at about $11 \mathrm{~km} \mathrm{~h}^{-13}$. The beam trawls are rigged with various ground gears, usually consisting of heavy chain mats or 'tickler' chains, that are designed to exclude rocks from the gear and to disturb and fluidise the upper layers of sediment and drive flatfish from the seabed and into the net. ${ }^{3}$ The penetration of the chains into the sediment, and hence the amount of physical disturbance caused by the beam trawl, depends on the weight of the gear, towing speed and sediment type. On soft muddy-sand bottoms, the gear will typically penetrate to a depth of around $6 \mathrm{~cm} .^{3}$

Beam trawling effort is extremely patchy, and fishers have favoured 'tows' which they trawl repeatedly while adjacent areas may be virtually unfished. Small areas of the North Sea are fished 5 or more times each year while others are virtually unfished. ${ }^{9}$ There are significant reductions in the biomass of large macrofauna in heavily trawled areas, ${ }^{10}$ because they cannot sustain the mortality rates caused by trawls. Direct mortalities of $5-65 \%$ have been recorded for larger invertebrate species in the path of a beam trawl, ${ }^{11}$ and these equate to annual fishing mortality rates of $5-39 \%$ in heavily trawled areas.

The relative impacts of trawling disturbance on sediments will depend on the relationship between trawling and natural sediment mixing. In shallow turbid regions such as the southern North Sea, wave and tidal actions lead to bulk sediment disturbance and transport ${ }^{12}$ and the effects of trawling are likely to be negligible. Moreover, the fauna living in these areas are likely to be well adapted to continual disturbance and more resilient to the effects of trawling. ${ }^{2,12}$ Conversely, in deeper 
areas with less natural disturbance, such as parts of the central North Sea, trawling disturbance is likely to account for a significant proportion of total disturbance. In areas with low natural disturbance, the biogeochemical impacts of trawling may be profound given that trawling kills macrobenthos and mixes sediments. Fluxes of $\mathrm{NO}_{2}{ }^{-}$and $\mathrm{NO}_{3}{ }^{-}$from sediment to the water column are a function of anaerobic carbon mineralisation coupled with aerobic oxidation of $\mathrm{NH}_{4}{ }^{+}{ }^{12}$ As these processes are mediated by microbial metabolic pathways and the bulk fluxes are altered by carbon mixing in sediments and the oxygen state, ${ }^{14}$ trawling activities should affect sediment biogeochemistry.

Soft sediment systems, such as those found in areas of low natural disturbance, are tightly coupled such that the organism biomass, carbon input chemical fluxes and storage are integrally linked. ${ }^{15,16}$ Bioturbation by macrobenthos is a key process for function and carbon mineralisation in the sediments as it mixes organic carbon, allows non-biochemical mediated oxidation of chemicals and oxygenates sediments. ${ }^{14}$ Bioturbation is at times a key process which maintains the benthic system in a dynamic steady state. ${ }^{16}$ As the large fauna in sediments are usually the bioturbators, their presence in the system may be integral to maintaining carbon mineralisation and sediment fluxes which may be considered the summary measure of "system function" and bioturbator loss from the system may break the close coupling present in a sediment system.

Trawling, by removing bioturbators from the system yet acting as a strong physical mixing force itself, will affect how a soft sediment system will mineralise carbon. The aim of the present work is to examine how carbon storage and mineralisation might be affected by trawling activities in areas where there are low levels of natural physical disturbance. These would be typical of beam trawling grounds in the deeper areas of the central North Sea, where mean sediment grain sizes are $0.05 \mathrm{~mm}$ or less. We examine two scenarios using a simple boxmodel of a soft sediment system: (1) a natural system with moderate macrofauna biomass; (2) a system with depressed macrofauna biomass and yet very intense anthropogenic mixing. These scenarios provide preliminary insights into the ways in which trawling disturbance can affect some ecosystem processes.

\section{Methods}

\section{The model}

To assess the potential impacts of trawling on carbon mineralisation in southern North Sea sediments we ran simulations using a previously described model of a generalised soft sediment system. ${ }^{16}$ This simulation model includes three bacterial compartments, meiofauna, macrofauna, oxic carbon, anoxic carbon and sulfide (Fig. 1). The model conserves carbon and carbon input and temperature are the external conditions applied to the model.

Each of the living compartments in the model grows in proportion to its consumption of carbon from various sources shown in Fig. 1. Predation, that is a predator eating a living prey and not a non-living carbon source, is modelled with a Weigert type of functional response ${ }^{17}$ but modified such that intraspecific competition is handled using a carrying capacity term. Though the carrying capacity term can create problems with the dynamics of a model it was thought to be suitable for the steady state simulations presented here. Furthermore, this is a useful formulation for holding biomass of a particular compartment at a defined level without modifying model structure. Using the carrying capacity term in this way allows comparison between scenarios that have different fixed biomass levels. This is an important consideration for both types of scenario examined in this study. Bacterial

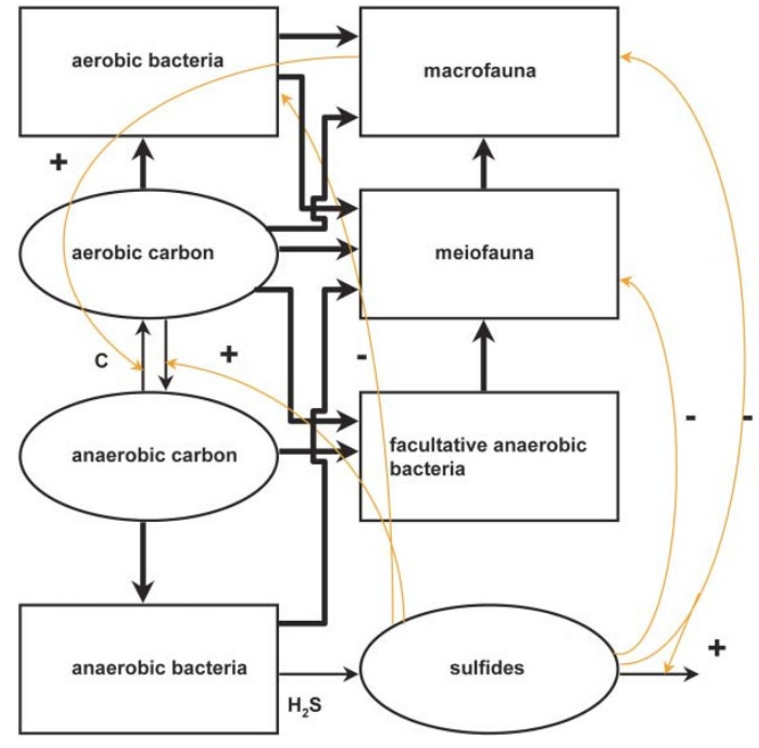

Fig. 1 Diagram of state variables and flows in a model of a soft sediment ecosystem. Thick line arrows are trophic carbon flows; thin line arrows are information flows indicating the influence of the state of a variable on a process, the + and - indicate the direction of the influence; arrows of intermediate line thickness are flows of carbon and sulfide. A detailed description of the model can be found in Duplisea. ${ }^{16}$

consumption of carbon is modelled as simply a basic linear numerical response modified by a carrying capacity term where the carrying capacity is set as the amount of carbon in the utilised compartment.

The model contains two opposing positive feedbacks which have previously been shown to be important for benthic community structure and flux rates in the model (Fig. 1). The first positive feedback is where sulfide release is increases as a function of bioturbation; hence, increases the rate of carbon flux into the oxic compartment from the anoxic carbon compartment. This is the equivalent of oxygenating the sediments and making more carbon available to the oxic fauna. The bioturbation effect is proportional to the biomass of macrofauna in the sediments by eqn. (1):

$$
\mathrm{BT}=2 \log _{10}(\text { MacrofaunaBiomass }+1)
$$

where macrofauna biomass is measured in $\mathrm{mmol}(\mathrm{C}) \mathrm{m}^{-2}$. BT is a multiplier of the basic flux rates. Generally it varies by a factor $<6.5$ with most levels of macrofauna biomass.

The opposing positive feedback is with sulfide production by anaerobic bacteria and the toxicity of this sulfide to metazoans. Anaerobic bacteria consume anoxic carbon and produce toxic sulfides in proportion to their carbon consumption. The stored sulfides then produce a toxic effect which increases the mortality rate of aerobic organisms as well as increases the rate of carbon flux from the oxic to the anoxic compartment. The sulfide toxicity is modelled as a function of stored sulfides by eqn. (2):

$$
\mathrm{ST}=2 \log _{10}(\text { StoredSulfide }+1)
$$

where sulfide storage is measured in $\mathrm{mmol}(\mathrm{S}) \mathrm{m}^{-2}$.

The key feature of the model which makes it useful for the current analysis is the bioturbation function. Bioturbation in the model has the direct effect of moving carbon between anoxic and oxic compartments as well as oxidising stored sulfides. This bioturbation factor was modified to simulate the mixing effects of trawling by setting the multiplier at fixed levels. Unfortunately, the multiplier cannot be directly related to observed levels of trawling disturbance because we do not know the effects of a single trawl pass on the movement of 
carbon between anoxic and oxic compartments or on the oxidation of stored sulfides. Such data could, however, be collected in an experimental study.

The model is described in greater detail elsewhere. ${ }^{16}$

\section{Simulations}

Scenario 1 "natural": bioturbation as a function of macrofauna biomass. For the first set of simulations macrofauna biomass was set at a fixed level by altering the carrying capacity for that compartment. For this type of simulation, the direct mixing effect of the trawling itself was not considered but was allowed to affect the benthic community only by modifying macrofauna biomass, hence following the relationship of eqn. (1); therefore macrofauna participated in all benthic processes in proportion to their biomass and were the sole sources of bioturbation. This type of scenario is unlikely in reality as benthic trawling kills macrofauna while at the same time mixing sediments and releasing stored sulfide. The scenario is necessary, however, as it provides a baseline situation for a community with a naturally low biomass of macrofauna.

Scenario 2 "trawling": low macrofauna biomass and intense physical mixing caused by trawling. The second set of simulations is probably more realistic as the macrofauna biomass in depressed (about $70 \mathrm{mmol}(\mathrm{C}) \mathrm{m}^{-2}$ ) yet the bioturbation-like mixing increases as a function of the trawling effort. The factor BT was therefore set at a constant level and run to steady state. For the present simulations, BT was varied between 1 and 20, hence the physical mixing effects of trawling were allowed to increase base rates by a factor of 20 . In this situation macrofauna has little to do with the modelled sediment fluxes as their biomass is kept so low.

All simulations were run to steady state. The results presented here are the steady state solutions for fixed levels of macrofauna for the natural scenario and fixed levels of bioturbation-like trawling and depressed macrofauna biomass (of less than $70 \mathrm{mmol}(\mathrm{C}) \mathrm{m}^{-2}$ ) for the trawling scenario.

\section{Results}

Macrobenthic biomass in the Silver Pit area of the central North Sea has been reduced by trawling activities (Fig. 2). This applies in other areas of the North Sea and can be expected generally. ${ }^{3,10}$ This analysis of the relationship between macrobenthic biomass and trawling activity suggests that

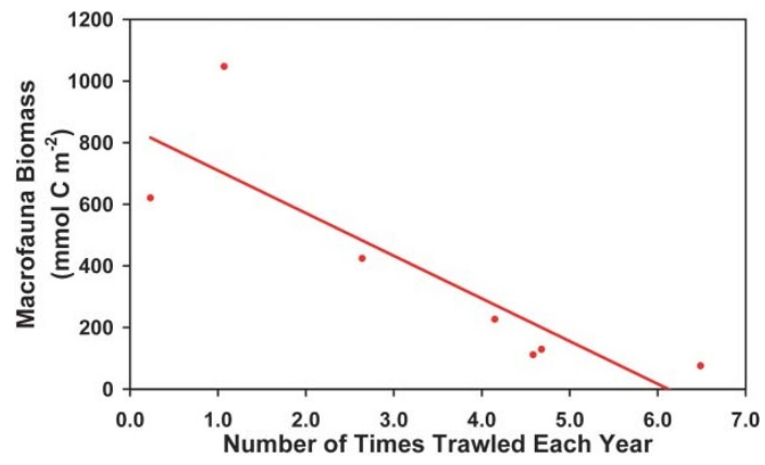

Fig. 2 Macroinfauna biomass in the Silver Pit area of the central North Sea in relation to beam trawling effort. Effort is expressed as the average number of times each year any area of the bottom is swept by beam trawling gear. Macrofauna biomass in $\mathrm{mmol}(\mathrm{C}) \mathrm{m}^{-2}$ has been converted from $\mathrm{g}$ (wet weight) $\mathrm{m}^{-2}$ by multiplying by factor of 10 . Data from Jennings et al. ${ }^{10}$ Preliminary analyses of these data showed that the decline in biomass was due to trawling rather than environmental factors such as depth, mean sediment diameter and sorting coefficient. ${ }^{19}$

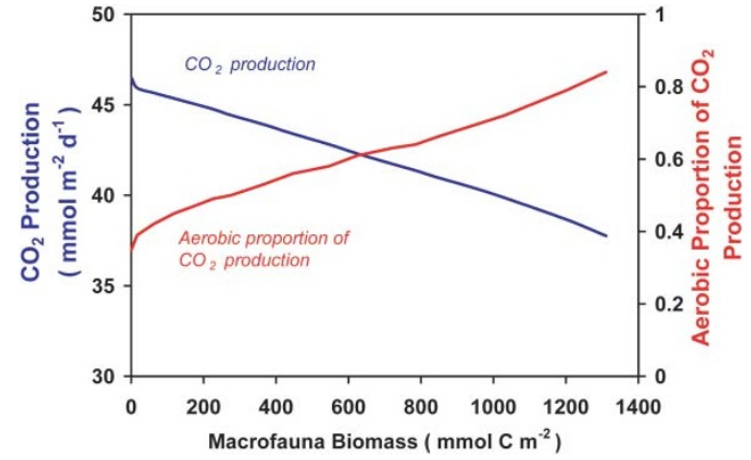

Fig. 3 Model simulation results showing steady state total benthic $\mathrm{CO}_{2}$ production and the proportion of that production due to direct aerobic processes as a function of macrofauna biomass. Macrofauna are the sole bioturbators/bioirrigators in the model.

macrobenthic biomass can be reduced by an order of magnitude due to trawling activity.

\section{Scenario 1 "natural": bioturbation as a function of macrofauna biomass}

The first set of scenarios examines how a generalised soft bottom benthic system mineralises carbon in relation to the macrobenthic biomass where macrobenthos are the bioturbators in the system. This set of scenarios show that as macrobenthic biomass increases from 0 to the maximum observed in the Silver Pit area of the central North Sea (Fig. 2), the total $\mathrm{CO}_{2}$ production of the system decreases from 46 to $37 \mathrm{mmol} \mathrm{m}^{-2} \mathrm{~d}^{-1}$ (Fig. 3). The proportion of carbon mineralisation $\left(\mathrm{CO}_{2}\right.$ production) due to direct aerobic processes increased from 34 to $85 \%$ with an increase in macrofauna biomass from 0 to $1300 \mathrm{mmol}(\mathrm{C}) \mathrm{m}^{-2}$.

The appearance of bioturbating macrofauna immediately decreases the amount of carbon in the oxic carbon compartment and shifts this carbon to the anoxic compartment (Fig. 4). Concomitant with the shift in carbon, the amount of sulfide stored decreases as the bioturbators facilitate sulfide oxidation. Further increases in macrofauna biomass leads to declines in anoxic carbon, oxic carbon and sulfide. Anoxic carbon, however, declines the most as this is the prime source of the organic carbon fuelling the increase in macrobenthic biomass.

\section{Scenario 2 "trawling": low macrofauna biomass and intense physical mixing caused by trawling}

Steady state $\mathrm{CO}_{2}$ production remained constant when the trawling-induced physical mixing multiplier (PMM) varied from 0 to 10 (Fig. 5). The proportion of carbon mineralisation accounted for by aerobic processes increased from 0.37 to 0.54 over the same range of PMM. Between PMM values of 10 and

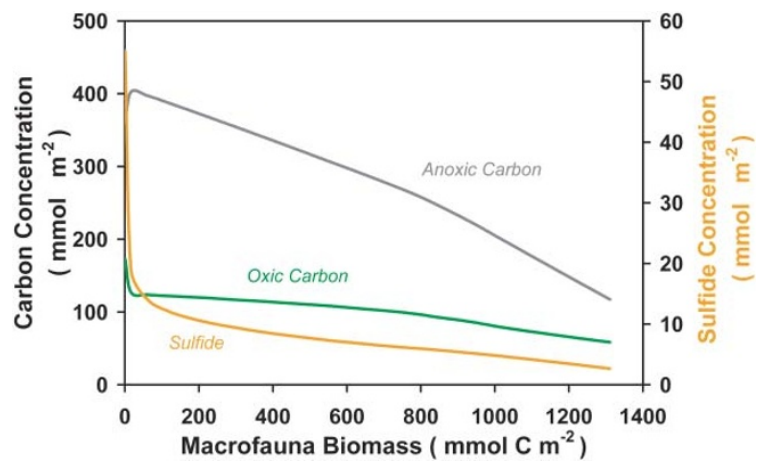

Fig. 4 Model simulation results showing steady state concentrations of sulfide, oxic organic carbon and anoxic organic carbon as a function of macrofauna biomass. Macrofauna are the sole bioturbators/bioirrigators in the model. 


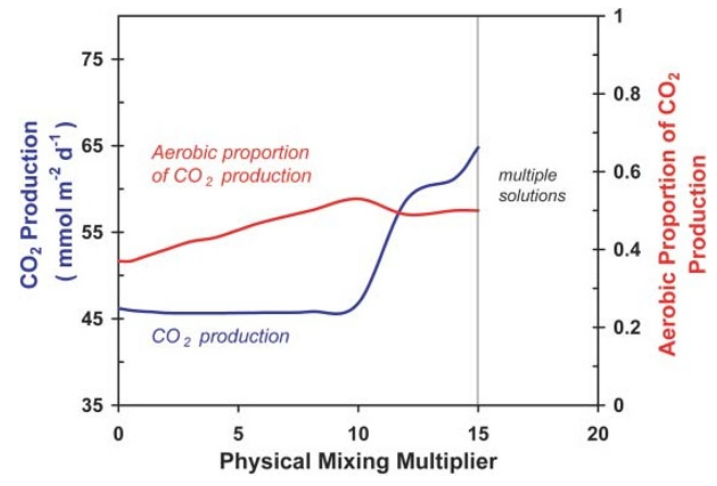

Fig. 5 Model simulation results showing steady state total benthic $\mathrm{CO}_{2}$ production and the proportion of that production due to direct aerobic processes as a function of physical mixing (PMM) hypothetically caused by trawling activity. Macrofauna are kept at a level of about $70 \mathrm{mmol}$ (C) $\mathrm{m}^{-2}$ for all simulations. At PMM levels greater than 15, the model has multiple solutions.

15, the mixing of carbon between compartments increased rapidly by about $30 \%$ above previous levels while the aerobic proportion of this production decreased slightly. After the PMM reached 16 the model became unstable and multiple solutions were found.

Sulfide storage in the sediment decreased greatly with a small initial increase in PMM (Fig. 6). The sulfide concentration decreased to a more constant and low level after the PMM value reached 10. Both carbon compartments remained at fairly constant levels until a PMM value of 10 where the exchange between compartments moved more carbon into the oxic compartment out of the anoxic compartment. Like the $\mathrm{CO}_{2}$ production the biomass of both compartments increased and the sulfide also increased to some degree. These increases were, however, unstable and at PMM values greater than 15 the model had multiple solutions.

To ascertain whether the modelled rates of $\mathrm{CO}_{2}$ production were realistic, the predicted rates were compared stoichiometrically with observed rates of total $\mathrm{N}$ flux. These measured rates were derived from summing separate observations of nitrate and ammonium flux at a site near the Silver Pit region of the North Sea. ${ }^{20}$

The mean total $\mathrm{N}$ flux was $c a .7-33 \mu \mathrm{mol} \mathrm{m}^{-2} \mathrm{~h}^{-1}$ and the upper range converts to $0.8 \mathrm{mmol} \mathrm{N} \mathrm{m}^{-2} \mathrm{~d}^{-1}$. Given that the accepted $\mathrm{N}: \mathrm{C}$ molar ratio in organic matter is $0.16,{ }^{18}$ the upper value equates to $\mathrm{CO}_{2}$ production of $5.5 \mathrm{mmol}(\mathrm{N})$ $\mathrm{m}^{-2} \mathrm{~d}^{-1}$ compared to a $\mathrm{CO}_{2}$ production range of 30 $50 \mathrm{mmol}(\mathrm{C}) \mathrm{m}^{-2} \mathrm{~d}^{-1}$ predicted by the model. The estimates of $\mathrm{CO}_{2}$ production derived from measured fluxes are somewhat lower than the model, but experimentally uncharacterised sediment processes such as coupled denitrification or microbial

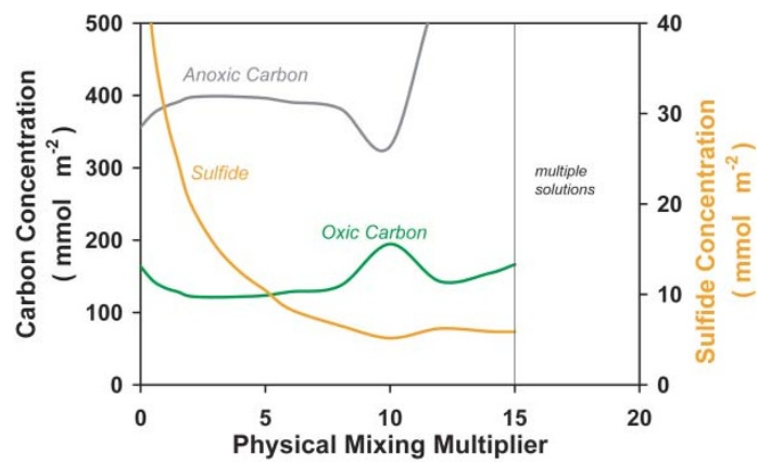

Fig. 6 Model simulation results showing steady state organic carbon and sulfide concentrations as a function of physical mixing (PMM) hypothetically caused by trawling activity. Macrofauna are kept at a level of about $70 \mathrm{mmol}(\mathrm{C}) \mathrm{m}^{-2}$ for all simulations. At PMM levels greater than 15 , the model has multiple solutions. utilisation can reduce the measured flux rates of $\mathrm{NH}_{4}$ and $\mathrm{NO}_{3}$ by a factor of $10 .^{21}$ Similar model comparisons of trawling impact scenarios could not be performed with this observational data but such work is planned in the near future and is designed to feed into modelling approaches.

\section{Discussion}

Our preliminary assessment of the effects of trawling disturbance on carbon mineralisation and chemical concentrations in a soft sediment system implies that trawling can have profound effects on functional processes in benthic systems. The model has been parameterised for a soft sediment system, which is typical of beam trawled areas in the deeper parts of the central North Sea. It is unlikely, however, that the model is applicable to the coarser sediments in shallow regions of the southern North Sea, where wave and tidal action are the main sources of physical disturbance.

Juxtaposing the natural scenario with the trawling scenario, the model predicts that physical mixing caused by macrofauna bioturbation will create quite different steady state benthic processes from physical mixing caused by trawling activities. The greatest of these differences is the instability in the modelled carbon and sulfide concentrations as well as carbon mineralisation rates in the trawling scenario. The trawling scenario shows large and rapid fluctuations in carbon and carbon mineralisation between oxic and anoxic compartments and carbon mineralisation pathways, respectively. In the natural scenario, macrofauna biomass shows considerable stability and there is explainable collective behaviour such as decreases in the anoxic carbon compartment which fuel increases in macrobenthic biomass. The contrast of the two scenarios suggests that the presence of a large macrobenthos biomass with slower rates needs to accompany increases in physical mixing of the sediments to prevent instabilities. This corroborates work showing that high variability in benthic biomass and rates (i.e. spatial instability which may be reflected in the present model through multiple solutions) reflects a disturbed community. ${ }^{22}$ It is likely that in an undisturbed situation slower growing macrofauna sequester a considerable amount of organic carbon that is unavailable for microbial processes. Therefore, shifts in carbon between availability and unavailability for various microbial processes cannot be large. When macrofauna are killed in the system through trawling, and physical mixing is very high, the model is unstable because of drastic shifts in carbon between available and unavailable to various microbial processes. As the bacterial turnover times are very high, their population biomass and community fluxes respond rapidly as well. Experimental work presented in this symposium $^{23}$ shows that a high level of physical mixing can stimulate anaerobic bacterial processes which is counter to the intuitive explanation of physical mixing as an aerobic favourable process.

The present model is carbon limited only and other molecules exist in stoichiometric relation to carbon and the relevant reaction pathway. In reality though, there is likely to be limitation of various molecules especially nitrogenous species. Modelling of nitrogen in the benthos would likely limit some of these pathways and may reduce the instability of the model in the trawling scenario. If, however, ammonium $\left(\mathrm{NH}_{4}{ }^{+}\right)$were nitrified $\left(\mathrm{NO}_{2}^{-}\right.$and $\left.\mathrm{NO}_{3}{ }^{-}\right)$and released to the overlying water at a higher rate due to trawling, which is a known result of bioturbation-like mixing, ${ }^{14}$ phytoplankton production in surface waters could be enhanced by trawling activity.

Although very little work ${ }^{24-26}$ has been done on trawling impacts on sediment function (i.e. rate of nutrient cycling, processes etc.) the immediate potential of nutrient release derived from recycling of benthic mortalities and sediment 
resuspension are clear. ${ }^{27}$ For example, given that the observed macrofauna biomass ranges between 600 and $1000 \mathrm{mmol}(\mathrm{C}) \mathrm{m}^{-2}$ which characterises the Silver Pit area, ${ }^{10}$ we can calculate the potential total $\mathrm{N}$ release from trawling induced mortality. Using direct mortality of $5-65 \%{ }^{11}$ and assuming that $50 \%$ of this is consumed by scavengers, mortality of macrofauna by a trawl could potentially produce an initial pulse of $15-423 \mathrm{mmol}(\mathrm{C}) \mathrm{m}^{-2}$ after the trawl passage. This converts to a release of between 2.4 and $68 \mathrm{mmol}(\mathrm{N}) \mathrm{m}^{-2}$ derived from recycling of this material. An $\mathrm{N}$ pulse of this magnitude over a large area could affect surface production. Clearly changes in macrofauna biomass with prolonged trawling or changing intensities and recycling rates/sediment processes will alter the actual flux speciation and rates.

In addition to $\mathrm{N}$ pulses from direct organism mortality other biogeochemical fluxes will change as a result of sediment resuspension. Preliminary empirical work ${ }^{28}$ in the Botney Cut region to the south-east of the Silver Pit, indicates that resuspension events in sediments impacted by trawling lead to larger fluxes of phosphate, silicate and nitrogenous species compared with untrawled sediments (Fig. 7). Such results suggests that the storage and probably recycling times of these compounds is decreased in trawled sediments.

We calculated a potential impact of trawling induced flux rate multiplier using flux rates from sediment resuspension experiments (Fig. 7) and typical North Sea beam trawler tow rates $^{29}$ and gear penetration depth. ${ }^{3}$ We estimated that a trawler will impact about $0.27 \mathrm{~km}^{2} \mathrm{~h}^{-1}$ to a depth of $c a .6 \mathrm{~cm}$. Assuming that all this sediment is resuspended during the trawler passage and using typical porosity $(0.65)$ and sediment specific gravity $\left(2.65 \mathrm{~g} \mathrm{~cm}^{-3}\right)$ estimated nutrient releases due to trawling are: $234 \pm 128 \mu \mathrm{mol} \mathrm{m}{ }^{-2} \mathrm{~h}^{-1} \mathrm{NO}_{3}$,

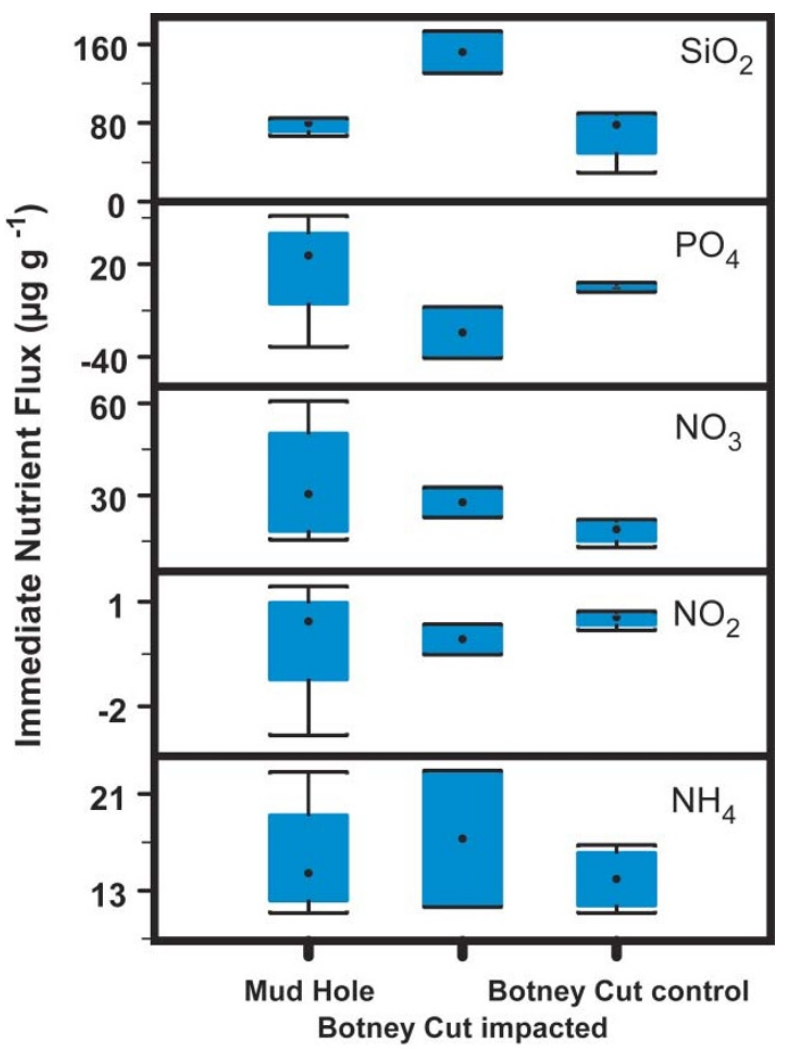

Fig. 7 Pulsed nutrient fluxes from intact sediment cores which were artificially resuspended under experimental conditions. All cores were from soft sediments areas of the central North Sea. Values are for immediate releases into the overlying water. Mud Hole and Botney Cut cores are from areas undisturbed by trawling. The Botney Cut Impacted cores were from an area which is regularly beam trawled. Bars represent ranges, boxes are standard deviations and points are medians.
$457 \pm 117 \mu \mathrm{mol} \mathrm{m}^{-2} \mathrm{~h}^{-1} \mathrm{NH}_{4}$, and $668 \pm 18 \mu \mathrm{mol} \mathrm{m}^{-2} \mathrm{~h}^{-1}$ silicate. These calculations indicate that a single trawl passage could potentially produce non-equilibrium pulsed releases of nitrate, ammonium and silicate that are 20, 45 and 26 times greater than the ambient undisturbed sediment nutrient flux, respectively. This will of course vary with sediment type and in the long term will be a function of the total nutrient status in the system, but it does indicate a change in the benthic system function. Nutrient releases to overlying water of this magnitude could affect surface production. ${ }^{27}$

It has been suggested that trawling activities "farm the sea". That is, trawling removes large long-lived species that are unavailable as food for commercially important benthic fish consequently freeing up resource for benthos that are better food sources for fish. ${ }^{10}$ The current study suggests that much of this released carbon could simply fuel microbial pathways rather than the metazoan fish food pathways, in accordance with the observation that almost all benthic metazoan production is reduced by trawling disturbance. ${ }^{10}$

The model describes the local effects of trawling and it is interesting to consider the cumulative impact of these effects. Clearly, trawling effort is very patchy, ${ }^{9}$ and while some areas of seabed are trawled $>4$ times per year, others are virtually unfished. Indeed, for the North Sea as a whole, at the scale of the ICES rectangle (211 rectangles of $0.5^{\circ}$ latitude by $1^{\circ}$ longitude: area of rectangle $3720 \mathrm{~km}^{2}$ at $53^{\circ} \mathrm{N}$ ), $50 \%$ of rectangles are beam trawled for less than $2000 \mathrm{~h} \mathrm{a}^{-1} .^{29}$ Since a typical beam trawler tows two $12 \mathrm{~m}$ (width) beams at 6 knots $\left(11.1 \mathrm{~km} \mathrm{~h}^{-1}\right)$, the trawler will impact about $535 \mathrm{~km}^{2}$ of substratum in $2000 \mathrm{~h}$. Thus, in rectangles subject to $2000 \mathrm{~h}$ beam trawling $\mathrm{a}^{-1}$, and with a truly homogeneous effort distribution in the rectangle, it would take at least 7 years to trawl the entire rectangle once. If we are to assess the cumulative impacts of trawling on biogeochemical processes in the North Sea, then future models of the effects of trawling disturbance on carbon mineralisation and chemical concentrations will need to incorporate explicit links between trawling frequency on different sediment types and the physical mixing multiplier used in our model (from experimental data) and to incorporate a spatial component that accounts for patchiness in trawling disturbance.

There have been few attempts to assess the significance of fishing activities on functional processes in the marine ecosystem. Our model, implies that trawling could strongly affect benthic biogeochemical fluxes which in turn may affect the carbon flow throughout the a marine ecosystem. The present modelling study, though speculative, suggests that trawling in the benthos could enhance microbial carbon mineralisation pathways at the expense of metazoan faunal biomass and intense trawling could create considerable instability in benthic function. This contrasts a modelled natural community which shows high stability and explicable collective community behaviours.

\section{Acknowledgements}

We thank Yoko Furukawa for her initiative and organising the symposium at ACS. Research was funded by CEFAS contract DP163, DEFRA contract MF0716 to Carl O'Brien and DEFRA contracts to Stephen Malcolm. ACI-Acknowledgement is made to the Donors of The Petroleum Research Fund, administered by the American Chemical Society, for partial support of the symposium. The symposium was also supported by American Office of Naval Research grant ONR 342.

\section{References}

1 P. K. Dayton, S. F. Thrush, M. T. Agardy and R. J. Hofman, Environmental effects of marine fishing, Aquat. Conserv., 1995, 5, 205-232. 
2 S. Jennings and M. J. Kaiser, The effects of fishing on marine ecosystems, Adv. Mar. Biol., 1998, 34, 201-352.

3 The effects of different types of fisheries on the North Sea and Irish Sea benthic invertebrates, ed. H. J. Lindboom and S. J. de Groot, Netherlands Institute of Sea Fisheries, Texel, 1998.

4 S. J. Hall, The effects of fishing on marine ecosystems and communities, Blackwell Science, Oxford, 1999.

5 J. S. Collie, S. J. Hall, M. J. Kaiser and I. R. Poiner, A quantitative analysis of fishing impacts on shelf sea benthos, J. Anim. Ecol., 2000, 69, 785-798.

6 M. J. Kaiser and S. J. de Groot, The effects of fishing on non-target species and habitats: biological, conservation and socio-economic issues, Blackwell Science, Oxford, 2000.

7 R. Parker, S. Malcolm and S. Jennings, The impact of disturbance on sediment ecosystem function and the quality of the coastal environment, MAFF contract report, 1999.

8 K. Gilkinson, M. Paulin, S. Hurley and P. Schwinghamer, Impacts of trawl door scouring on infaunal bivalves: results of a physical trawl door modelldense sand interaction, J. Exp. Mar. Biol. Ecol., 1998, 224, 291-312.

9 A. D. Rijnsdorp, A. M. Bujis, F. Storbeck and E. Visser, Microscale distribution of beam trawl effort in the southern North Sea between 1993 and 1996 in relation to the trawling frequency of the sea bed and the distribution of benthic organisms, ICES J. Mar. Sci., 1998, 55, 403-419.

10 S. Jennings, T. A. Dinmore, D. E. Duplisea, K. J. Warr and J. E. Lancaster, Trawling disturbance can modify benthic production processes, J. Anim. Ecol., 2001, 70, 459-475.

11 M. J. N. Bergman and J. W. van Santbrink, "Fishing mortality of populations of megafauna in sandy sediments", in Effects of fishing on non-target species and habitats: biological, conservation and socio-economic issues, ed. M. J. Kaiser and S. J. de Groot, Blackwell Science, Oxford, 2000, pp. 49-68.

12 M. J. Kaiser, Significance of bottom-fishing disturbance, Conserv. Biol., 1998, 12, 1230-1235.

13 W. H. Schlesinger, Biogeochemistry: an analysis of global change, Academic Press, San Diego, 1997.

14 G. Krantzenberg, The influence of bioturbation on physical, chemical and biological parameters in aquatic environments: a review, Environ. Pollut., Ser. A, 1985, 39, 99-122.

15 A. E. Giblin, K. H. Foreman and G. T. Banta, "Biogeochemical processes and marine benthic community structure: which follows which?" in Linking species and ecosystems, ed. C. G. Jones and J. H. Lawton, Chapman and Hall, 1995, pp. 37-44.
16 D. E. Duplisea, Feedbacks between benthic carbon mineralisation and community structure: a simulation-model analysis, Ecol. Mod., 1998, 110, 19-44.

17 P. Chardy and J. C. Dauvin, Carbon flows in a subtidal fine sand community from the western English Channel: a simulation analysis, Mar. Ecol. Prog. Ser., 1992, 81, 147-161.

18 T. H. Blackburn, "Benthic mineralisation and bacterial production", in Nitrogen cycling in coastal marine environments, ed. T. H. Blackburn and J. Sorensen, Wiley and Sons, New York, 1988, pp. 175-190.

19 D. E. Duplisea, S. Jennings, K. Warr and T. Dinmore, A size-based model to predict the impacts of bottom trawling on benthic community structure, in preparation.

20 D. B. Sivyer and R. Parker, unpublished.

21 D. B. Sivyer, Nitrogen cycling in intertidal sediments of the Wash, $U K$, MSc by Research Thesis, School of Environmental Sciences, University of East Anglia, 1999.

22 R. M. Warwick and K. R. Clarke, Increased variability as a symptom of stress in marine communities, J. Exp. Mar. Biol. Ecol., 1993, 172, 215-225.

23 M.-Y. Sun, W.-J. Cai, S. B. Joye, H. Ding, J. Dai and J. T. Hollibaugh, Degradation of algal lipids in microcosm sediments with different mixing regimes, Org. Geochem., 2002, in press.

24 P. Krost 1990, The impact of Otter-trawl fishery on nutrient release from the sediment and macrofauna of Kiel Bay (Western Baltic), Institut für Meereskunde report no. 200, Kiel, Germany, p. 167.

25 C. H. Pilskaln, J. H. Churchill and L. M. Mayer, Resuspension of sediment by bottom trawling in the Gulf of Maine and potential geochemical consequences, Conserv. Biol., 1998, 12, 1223-1229.

26 C. J. Smith, K. N. Papadopoulou and S. Diliberto, Impact of otter trawling on an eastern Mediterranean commercial trawl fishing ground, ICES J. Mar. Sci., 2000, 57, 1340-1351.

27 T. H. Blackburn, Release of nitrogen compounds following resuspension of sediment: model predictions, J. Mar. Syst., 1997, 11, 343-352. 28 R. Parker and D. B. Sivyer, unpublished.

29 S. Jennings, J. Alvsvåg, A. J. Cotter, S. Ehrich, S. P. R. Greenstreet, A. Jarre-Teichmann, N. Mergardt, A. D. Rijnsdorp and O. Smedstad, Fishing effects in north-east Atlantic shelf seas: patterns in fishing effort, diversity and community structure. III. International fishing effort in the North Sea: an analysis of temporal and spatial trends, Fish. Res., 1999, 40, 125-134. 